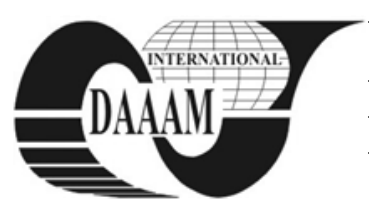

Annals of DAAAM for 2011 \& Proceedings of the 22nd International DAAAM Symposium, Volume 22, No. 1, ISSN 1726-9679 ISBN 978-3-901509-83-4, Editor B. Katalinic, Published by DAAAM International, Vienna, Austria, EU, 2011 Make Harmony between Technology and Nature, and Your Mind will Fly Free as a Bird Annals \& Proceedings of DAAAM International 2011

\title{
APPLICATION OF FINITE ELEMENT METHOD IN PILE WALL MODELING
}

\author{
PRSKALO, M[aja] \& COLAK, A[nela]
}

\begin{abstract}
The method used in this paper to protect a construction pit by a pile wall is based on checking the stability of the pile wall in the program GEO5 - FEM (Finite Element Method), which gives values of stresses and strains in soil. Since safety factors obtained by the program were small, indicating structural instability, it is necessary to additionally support the structure by struts. The adopted solutions obtained in Sheeting Check (GEO 5) are based on Eurocode 7, specifically using the design approach DA1, combination 1 and combination 2, adopting adequate partial coefficients
\end{abstract}

Key words: construction pit, pile wall, finite element method,Eurocode 7

\section{INTRODUCTION}

The common geotechnical practice is to use modern numerical methods, such as the finite element method, differential method, and boundary element method. These methods model the soil-structure interaction and analyze stressstrain states in the foundation soil and structure in all construction stages. Unlike usual analytical methods, which directly calculate dimensions of support structures (such as anchors, struts etc.), numerical methods require support structures to be predefined (Logar, 2009).

\section{PREVIOUS RESEARCH}

Various theoretical and numerical procedures are developed to obtain approximate solutions of real distribution of stresses in a structure-soil interface. A practically reasonable approximation of the actual state is achieved by developing numerical procedures and thoroughly investigating deformation properties of soil (Veric, 2000).

GEO5 is a set of programs designed for solving geotechnical problems and each of the programs is intended for solving a different geotechnical problem. The programs are based on the analytical calculation method and finite element method (FEM), Figure 1. By using the finite element method, the FEM program evaluates stresses and strains in soil around a structure and stability of the structure. Finite element method computations of the FEM program established that our sheetpile wall was unstable without support, i.e. without a strut. For that reason, further computations were carried out using the Sheeting Check program, with a strut placed 3.0 in depth and sized based on acting forces. Sheeting Check allows wall stability testing and provides moments and forces acting on the pile wall.

\section{NUMERICAL METHODS}

With these calculations, we obtain ultimate states of bearing capacity in terms of characteristic values of parameters of soil and structure and characteristic geometry of elements of the structure, anchor and strut, which are considered as linear elastic elements with regard to actual characteristic stiffness.

Sizing is performed based on values of forces obtained according to EC7, with application of partial factors.

The geotechnical Eurocode (Eurocode 7, 1997) consists of two parts:

- EN 1997-1 Geotechnical design - Part 1: General rules

- EN 1997-2 Geotechnical design - Part 2: Ground investigation and testing.

The entire structure and stiffness of structural elements must be predefined for calculation according to the finite element method. Diaphragm should be calculated as elastic linear elements with constant stiffness. For the C25/30 quality concrete, $30 \mathrm{GPa}$ is adopted as the value of modulus of elasticity. The volume weight of concrete is $\gamma=25 \mathrm{kN} / \mathrm{m} 3$.

Structural calculation is generally carried out in the following steps:

- selection of characteristic values of material parameters,

- selection of the depth to which piles are driven,

- stress-strain analysis of the structure using the finite element method and sizing of elements of the protective structure,

- calculation of active pressures and equivalent forces acting on the pile wall.

\section{EXAMPLES OF NUMERICAL MODELING}

Calculations of stability and strains of a pile wall solution $40 \mathrm{~cm}$ in thickness were carried out by geostatic analyses. After that, sizing of piles and strut elements was performed. We selected the piles $400 \mathrm{~mm}$ in diameter and 11 and $12 \mathrm{~m}$ in length, with the axis-to-axis distance of $70 \mathrm{~cm}$. Considering the presence of groundwater above the design excavation bottom, a low-permeability barrier was used as the design solution to protect the construction pit. Grouting decreased permeability of the medium and made the whole barrier low-permeable. Temporary struts were also placed as an extra protection measure because the pile wall alone did not provide sufficient safety.

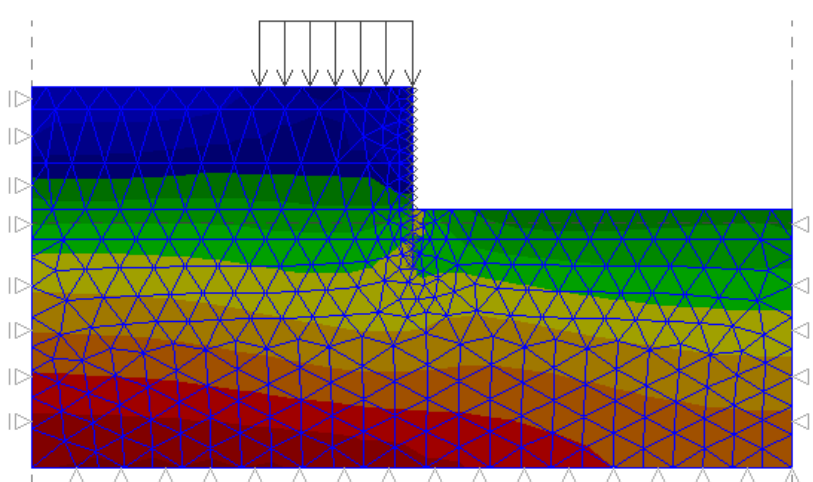

Fig. 1. Results obtained using the FEM method 


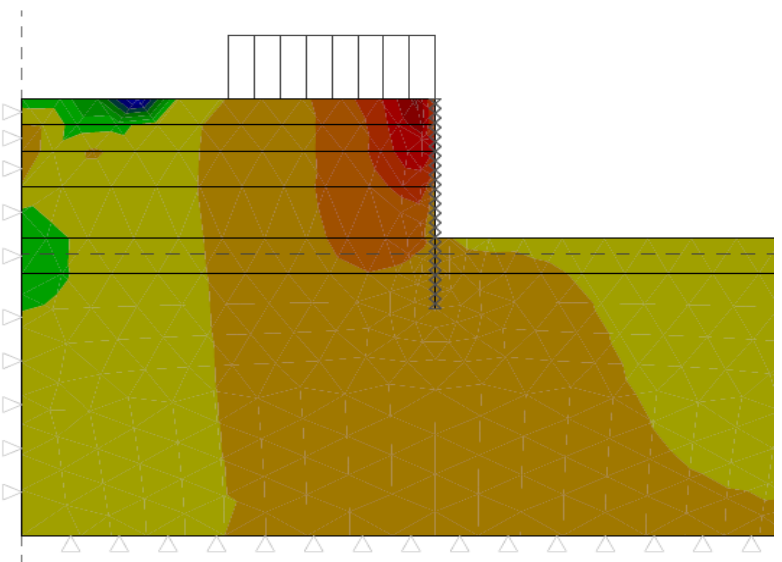

Fig. 2. Results obtained by the FEM method, settlement of soil

Struts were placed horizontally to support strut beams along the pile wall. Metal HEB profiles, sized according to acting forces, were used as struts and strut beams. One of the solutions obtained using the finite element method in the FEM program is shown in Figure 2.

It is always necessary to choose a suitable model of soil with adequately described changes that occur when excavating a construction pit. To model such problems, it is generally appropriate to use a non-linear model of soil with consolidation (e.g. the Hardening Soil Model) because of non-uniform pressures. For simplicity of the example, an ideal elasto-plastic Mohr-Coulomb model of soil, with characteristics equal to those applied in the analytical calculation, is selected here. Some computer programs for design based on the finite element method also allow numerical calculations of groundwater flows in stationary and non-stationary conditions. Effects of moments and transverse forces on the pile wall were calculated according to the design approach 1, combinations 1 and 2, with values of partial safety factors shown in Table 1 .

The value of active pressure acting on the pile structure is taken as a continuous load on the strut beam. This solution is conservative because it assumes that the strut beam takes the full equivalent force of active pressure, fully disregarding rigidity of the pile wall, but it is on the safe side and justified in view of possible consequences of oversizing. Values of active pressure forces are applied as a continuous load and we obtained the maximum values of moment and transverse forces, horizontal displacement and pressures on the diaphragm under effects of the active pressure, Table 2, Figures 3, 4.

\begin{tabular}{|l|r|r|r|}
\hline $\begin{array}{l}\text { Design } \\
\text { approach } \\
\text { DA1 }\end{array}$ & Effects & $\begin{array}{l}\text { Soil } \\
\text { parameters }\end{array}$ & $\begin{array}{c}\text { Soil resistance } \\
\text { R1 }\end{array}$ \\
\hline $\begin{array}{c}\text { Combination } \\
1\end{array}$ & $\gamma_{\mathrm{G}}=1.35$ & $\gamma_{\varphi}=\gamma_{\mathrm{c}}=1.0$ & $\gamma_{\mathrm{R} ; \mathrm{e}}=\gamma_{\mathrm{R} ; \mathrm{v}}=1.0$ \\
$\gamma_{\mathrm{Q}}=1.5$ & $\gamma_{\mathrm{cu}}=1.0$ & $\gamma_{\mathrm{R} ; \mathrm{h}}=1.0$ \\
\hline $\begin{array}{c}\text { Combination } \\
2\end{array}$ & $\gamma_{\mathrm{G}}=1.35$ & $\gamma_{\varphi}=\gamma_{\mathrm{c}}=1.0$ & $\gamma_{\mathrm{R} ; \mathrm{e}}=\gamma_{\mathrm{R} ; \mathrm{v}}=1.0$ \\
$\gamma_{\mathrm{Q}}=1.5$ & $\gamma_{\mathrm{cu}}=1.0$ & $\gamma_{\mathrm{R} ; \mathrm{h}}=1.0$ \\
\hline
\end{tabular}

Tab. 1. Values of partial safety factors for support structures design approach PP1 (Prskalo, 2011)

\begin{tabular}{|c|c|c|c|}
\hline $\begin{array}{c}\text { Design } \\
\text { approach DA1 }\end{array}$ & $\begin{array}{c}\mathrm{M}_{\max } \\
(\mathrm{kNm} / \mathrm{m})\end{array}$ & $\begin{array}{c}\mathrm{Q}_{\max } \\
(\mathrm{kN} / \mathrm{m})\end{array}$ & $\begin{array}{c}\text { Horizontal } \\
\text { displacement } \\
\text { of the } \\
\text { diaphragm } \\
\mathrm{U}_{\max }(\mathrm{mm})\end{array}$ \\
\hline Combination 1 & 202.64 & 167.94 & 10.5 \\
\hline Combination 2 & 150.69 & 127.50 & 9.1 \\
\hline
\end{tabular}

Tab. 2. Results of calculation according to the finite element method

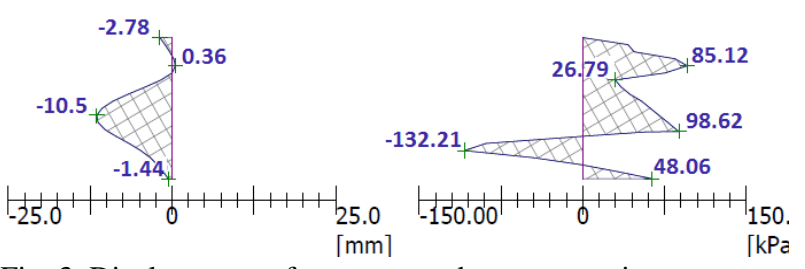

Fig. 3. Displacement of structure and pressure acting on structure PP1, combination 1

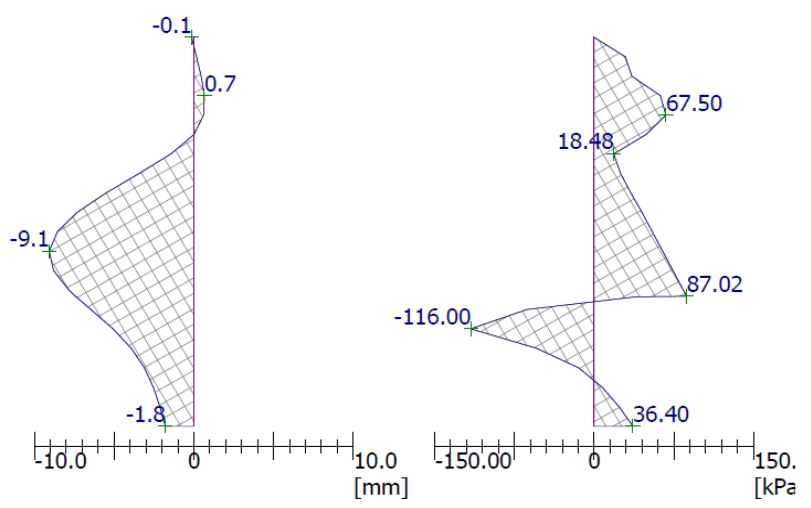

Fig. 4. Displacement of structure and pressure acting on structure PP1, combination 2

\section{CONCLUSION}

To ensure safe work during construction of the foundation and basement, the construction pit situated close to urban environment (two structures, roads and underground installations) was protected according to design elements and investigation results.

Sizing of the pile wall was carried out on the basis of the forces computed using the software suite (GEO5, 2010). Results of calculations based on the finite element method gave the values of maximum moment, maximum transverse force, and maximum horizontal displacement of the diaphragm according to Eurocode 7, design approach 1, combinations 1 and 2, with previously defined parameters of the support structure, and they serve as a basis for further pile wall stability calculations.

\section{REFERENCES}

Eurocode 7, (1997). Part 1 (BS EN 1997-1) Geotechnical design-General rules and Part 2 (prEN 1997-2) Ground investigation and testing

Logar, J. \& Pulko, B. (2009). Priročnik za projektiranje gradbenih konstrukcij po evrokod standardih (Guide for design of engineering structures according to Eurocode standards), Evrokod 7: Geotehničko projektiranje, Univerza v Ljubljani, Fakulteta za gradbeništvo in geodezijo, ISBN: 978-961-6724-03-6, Ljubljana

Prskalo, M. (2011). Zbirka riješenih zadataka iz Mehanike tla s primjenom EC 7 (Book of solved problems in soil mechanics with application of EC7), Faculty of Civil Engineering, University of Mostar

Verić, F. (2000). Savitljive temeljne konstrukcije (Flexible foundation structures), Authorized lectures, Faculty of Civil Engineering, University of Zagreb, Institute for Geotechnics

*** GEO 5 (2010) FEM, SHEETING CHECK, Software, version 5.10.32.0, www.finesoftware.eu 